\title{
Peran Foto Toraks Sebagai Alat Bantu Diagnostik pada Fase Akut Penyakit Kawasaki
}

Najib Advani, Lucyana Alim Santoso

Departemen Ilmu Kesehatan Anak Fakultas Kedokteran Universitas Indonesia Rumah SakiT Dr Cipto Mangunkusumo, Jakarta

Latar belakang. Belum ada pemeriksaan penunjang yang dapat memastikan diagnosis penyakit Kawasaki (PK) yang saat ini ditegakkan menggunakan kriteria klinis. Pemeriksaan penunjang tambahan dapat membantu dalam menegakkan diagnosis, meskipun tidak definitif.

Tujuan. Mengetahui apakah foto toraks dapat digunakan sebagai alat bantu diagnostik pada penyakit Kawasaki.

Metode. Penelitian ini adalah penelitian retrospektif data rekam medis pasien penyakit Kawasaki di beberapa rumah sakit sejak Januari 2003 hingga Desember 2018. Kriteria inklusi adalah anak yang memenuhi kriteria diagnostik penyakit Kawasaki dari American Heart Association, baik komplet maupun tidak komplet serta memiliki data lengkap klinis, ekokardiografi, dan foto toraks.

Hasil. Terdapat 916 subyek yang memenuhi kriteria inklusi dan 786 (86\%), di antaranya memiliki kelainan foto toraks. Kelainan terbanyak yang dijumpai adalah bercak infiltrat bilateral (84\%). Tidak ada perbedaan bermakna pada frekuensi kelainan foto toraks pada PK komplet maupun tidak komplet.

Kesimpulan. Tingginya angka kejadian kelainan paru pada foto toraks anak dengan PK maka foto toraks dapat digunakan sebagai alat diagnostik tambahan pada kasus PK tidak komplet. Sari Pediatri 2019;20(6):331-4

Kata kunci: penyakit Kawasaki, foto toraks, diagnostik

\section{The Role of Chest X-Ray as an Additional Tool in Acute Phase of Kawasaki Disease}

Najib Advani, Lucyana Alim Santoso

Background. As there is no specific diagnostic tool, diagnosis of Kawasaki disease is sometimes not easy and doubtful especially in incomplete type. Additional diagnostic tool in this case chest $\mathrm{x}$-ray, even not confirmed, may be of value in supporting the diagnosis. Objective. To investigate the role of chest $\mathrm{x}$-ray as an additional diagnostic tool in Kawasaki disease.

Method. A retrospective study from the data of children with Kawasaki disease as of January 2003 up to December 2018. Inclusion criteria are children who meet the diagnostic criteria of American Heart Association either for complete or incomplete type, with complete clinical, echocardiography and chest $x$-ray data.

Result. We found 916 children who met the inclusion criteria, among whom 786 subjects had abnormalities in chest x-ray, and the most common one was bilateral infiltrates on both lungs. There was no statistically significant difference in the frequency of chest $\mathrm{x}$-ray abnormalities between the complete and incomplete cases.

Conclusion. Chest x-ray may be of value as a diagnostic tool to support the diagnosis of Kawasaki disease especially in doubtful or incomplete cases. Sari Pediatri 2019;20(6):331-4

Keyword: Kawasaki disease, chest x-ray, diagnostic

Alamat korespondensi: Najib Advani. Departemen Ilmu Kesehatan Anak Fakultas Kedokteran Universitas Indonesia Rumah SakiT Dr Cipto Mangunkusumo, Jakarta. Email: najib.advani@gmail.com 
$\mathrm{P}$

yakit Kawasaki (PK) adalah suatu vaskulitis nak balita. Di negara maju, PK merupaka penyakit jantung didapat yang paling sering ditemukan pada anak. Jepang merupakan negara yang memiliki insiden Kawasaki tertinggi di dunia, denga angka kejadian per tahunnya adalah 265/100.000

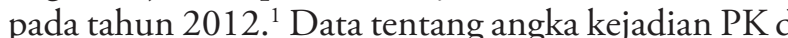
Indonesia belum ada, tetapi menurut estimasi terdapat sekitar 5000 kasus baru pertahun. ${ }^{2}$

Diagnosis PK ditegakkan berdasarkan gejala dan anda klinis dibantu hasil laboratorium berdasarka kriteria American Heart Association. ${ }^{2}$ Hingas sat ini belum ada suatu pemeriksan penunjang yan ini belif untuk memastikan diagnosis PK. G a yang paru abnorml pada for dorks penylic Kawask pernah dilaporkan olch beberapa peneliti sebelumny

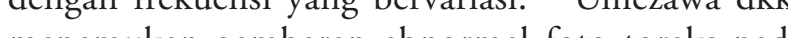
147\% wan Pa Ten abnormal foto toraks pada $14,7 \%$ pasien TK. Temant tersening adalah ganbaran

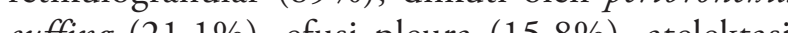
cuffing $(21,1 \%)$, efusi pleura $(15,8 \%)$, atelektasis $(10,5 \%)$ dan air trapping $(5,3 \%)$, yang biasa dijumpa pada 10 hari awitan penyakit. ${ }^{4}$ Mengingat adany

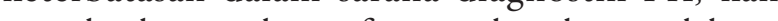
meneliti kemungkinan foto toraks sebagai salah satu alat bantu diagnostik terutama pada kasus yang tidak kompletatau meragukan.

\section{Metode}

Penelitian ini menggunakan data retrospektif pasien PK sejak 1 Januari 2003 sampai 31 Desember 2018 pada lima rumah sakit di Jakarta dan sekitarnya. Kriteria inklusi adalah semua pasien penyakit Kawasaki yang komplet maupun tidak komplet dengan data klinis, ekokardiografi dan foto toraks (setidaknya posisi antero posterior)dan ekokardiografi yan lengkap. Kriteria diagnostik Kawasaki berdasarkan pada pedoman dari American Heart Association, ${ }^{2}$ yaitu demam yang berlangsung selama $\geq 5$ hari diserta injeksi konjungtiva bilateral non purulen, perubahan daerah oral seperti lidah stroberi, bibir pecah-pecah dan kemerahan, limfadenopati servikal unilateral, da peruban pada ekstremitas, seperti eritema palmar dan plantar, pengelupasan telapak tangan/ kaki, ruam polimorfik serta pembesaran keleniar geth bening sevikal unilateral. Penyakit Kawasaki dikatakan komplet jika didapatkan kriteria demam ditambah 4 dari 5 kriteria lain, sedangkan Kawasaki tidak komplet jii terdapat kriteria demam ditambah 2-3 kriteria lain da ditemukan kelainan arteri koroner pada ekokardiograf. Data foto toraks dicatat abnormalitas dan deskripsinya. Semua pasien didiagnosis dan diterapi sendiri oleh penulis utama (NA) dan semua hasil foto toraks dibaca oleh dokter spesialis radiologi (SpRad). Pemeriksaan ekokardiografi semua dilakukan oleh peneliti dengan berpedoman pada kriteria American Heart Association. Analisis data mengounakan kai kuadrat dengan nila Analsis data dieksklusi.

\section{Hasil}

Kami mendapatkan 1474 anak dengan PK sepanjang periode Januari 2003 hingga Desember 2018. Terdapar 916 subjek dengan data klinis dan radiologik yang lengkap (Tabel 1) dengan mayoritas (75\%) PK komplet Kelainan pada foto toraks ditemukan pada 786 kasus (86\%) (Tabel 2). Gambaran radiologis normal terdapa ada 130 kasus $(14 \%)$. Kelainan yang utama $(84 \%)$ dalah infiltrat bilateral pada kedua paru (Tabel 3). Pada semua foto torak yang diteliti, gambaran jantung normal dan tidak ditemukan adanya kelainan bentuk jantung maupun kardiomegali. Subyek lelaki ternyata

Tabel 1. Karakteristik subjek yang dilakukan pemeriksaan foto toraks

Variabel Total $(\mathrm{n}=916)$

Gender, $\mathrm{n}$

Lelaki

Perempuan

$567(62)$

Usia, rerata, bulan (SB)

$348(38)$

Kawasaki komplet, $\mathrm{n}(\%)$

(2)

Kawasaki tidak komplet, $\mathrm{n}(\%)$

$682(75)$

lebih banyak dari perempuan dengan rasio 62/38 atau 1,6. Tidak ditemukan perbedaan yang bermakna pada frekuensi kelainan foto toraks pada penyakit Kawasaki komplet dan tidak komplet (Tabel 2)

\section{Pembahasan}

Kami mendapatkan dari 916 pasien yang memenuhi kriteria inklusi, 786 menunjukkan kelainan pada foto
Tabel 2. Hubungan antara jenis PK dan dilatasi arteri koroner dengan abnormalitas foto toraks

\begin{tabular}{lccc}
\hline & Radiologis abnormal, $\mathrm{n}(\%)$ & Radiologis normal, $\mathrm{n}(\%)$ & $\mathrm{p}(<0,05)$ \\
\hline Komplet & $591(75,2)$ & $91(70)$ & 0,209 \\
Tidak komplet & $195(24,8)$ & $39(30)$ & \\
Dilatasi koroner & & & \\
$\quad$ Ya & $142(18,5)$ & $34(27,2)$ & 0,23 \\
$\quad$ Tidak & $626(81,5)$ & $91(72,8)$ & \\
\hline Total & 786 & 130 & \\
\hline
\end{tabular}

Tabel 3. Distribusi radiologis abnormal pada subjek \begin{tabular}{ll}
\hline Temuan radiologik & Jumlah, $\mathrm{n}$ \\
\hline Bercak infiltrat bilateral & $660(84)$ \\
\hline Bercak & $118(15)$
\end{tabular} Bercak infiltrat unilateral $118(15)$ Penebalan hilus/ limfadenopati $\quad 2(0,3)$ Konsolidasi + air bronchogram $\quad 2(0,3)$ Atelektasis + infiltrat $1(0,1)$ Efusi pleura kanan $2(0,3)$ Pneumonia lobaits $1(0,1)$

Efusi + infiltrat $1(0,1)$

toraks mereka. Rasio lelaki dibanding perempuan adala $1,6: 1$. Hal ini sesuai dengan semua hasil penelitian yang mendapatkan dominasi lelaki pada PK. ${ }^{2}$ Data yang kami dapat tentang kelainan pada foto toraks berbeda dengan yang didapat oleh Umezawa dkk yang mendapatkan hanya $14,7 \%$ anak dengan PK yan yang mendapatkan hanya $14,7 \%$ anak dengan PKyang dengan penelitian kami yang mengambil subyek PK komplet dan tidak komplet, subyek mereka hany menggunakan pasien PK yang komplet. Hasil penelitia kami mirip dengan yang didapat oleh Moriya dkk' $y a n$ mendapatkan 82,6\% subyek pada fase akut PK yang menunjukkan abnormalitas berupa infiltrat pada paru, atau penelitian Uramoto yang mendapatkan angk $63 \%$ kelainan radiologik. Jika angka kejadian kelaina foto toraks tinggi maka terdapat kemungkinan untuk dijadikan alat bantu diagnostik.

Pada otopsi, pneumonia interstitial dijumpai pada 30\%-90\% pasien PK akut, sedangkan arteritis pulmonal dijumpai pada $45-71 \%$ kasus. ${ }^{7}$ Kedua kondisi in dapat menyebabkan abnormalitas gambaran pad foto toraks. Derajat kelainan paru secara radiologik umumnya sebanding dengan derajat kelainan secar anatomik. Mungkin pada kasus dengan deraja kelainan anatomi yang ringan sekali tidak atau belum dapat terdeteksi secara radiologik

Kekuatan penelitian ini adalah pada jumlah sampel yang besar dan semuanya didiagnosis dan terapi oleh peneliti sendiri sehingga dari segi diagnosis dan tata laksana terdapat keseragaman. Pada penelitian ini, kami tidak membandingkan dengan foto tora sudah direncanakan, tetapi terbentur masalah etik dan persetujuan orang tua karena terdapas efek radiasi, persetujuan orang tua karena terdapat efek radiasi, meskipun kecil jumlahnya. Namun demikian, kami berasumsi bahwa pada anak yang sehat, hasil foto toraksnya juga akan normal. Pada anak dengan gejala batuk atau pilek mungkin saja ditemukan infiltrat pada foto toraks, tetapi batuk pilek bukanlah gejala lazim pada PK sehingga kemungkinan yang kecil ini dapat diabaikan. Pada beberapa kasus yang awalnya dirujuk dengan diagnosis suspek PK dan mengami gejala batuk pilek yang kuat ternyata dalam pengamatan selanjutnya menderita morbili dan bukan PK.

Interpretasi foto pasien dilakukan oleh beberapa radiolog yang berbeda untuk pasien yang berbeda. Kami tidak menafikan kemungkinan akan adanya perbedaan faktor subjektivitas pada pembacaan foto, tetapi agaknya perbedaannya mungkin tidak akan terlalu bermakna mengingat mereka semua adalah spesialis radiologi dan kelainan radiologis yang tampak dalah kelainan yang sederhana.

Dignosis PK pada kasus yang komplet (memenuhi kriteria diagnostik) relatif tidak terlalu sulit. Namun, pada kasus yang tidak komplet, yaitu tidak semua gejala dan tanda kriteria diagnostik muncul, diagnosis kadang membingungkan dan dibutuhkan pengalaman dokter. Mengingat frekuensi kelainan radiologis yang tinggi pada penderita PK, baik yang komplet maupun tidak komplet, meski tidak spesifik, kami menganjurkan pemeriksaan foto toraks anteroposterior, terutama pada pasien PK tidak komplet yang diagnosisnya meragukan. Jika pada hasil foto toraks ditemukan kelainan, mungkin dapat menambah nilai diagnostik. Meski demikian, kemungkinan penyebab lain gambaran kelainan paru tersebut perlu juga dipikirkan. Mungkin masih diperlukan penelitian lebih lanjut dalam skala yang lebih besar secara prospektif agar dapat lebih 
memastikan hasil yang didapatkan pada penelitian ini. Kami menyadari bahwa foto toraks semata tidak punya arti dalam penegakan diagnosis PK dan tujuan penelitian ini bukanlah menggunakan foto toraks sebagai uji diagnostik. Akan tetapi, hasil foto toraks jika dikombinasikan dengan gejala dan tanda klinis yang lain dapat bersifat sebagai penunjang diagnostik

\section{Kesimpulan}

Dari hasil yang kami dapat dapat disimpulkan bahwa angka kejadian kelainan foto toraks pada fase akut penyakit Kawasaki cukup tinggi sehingga mungkin dapat dipakai untuk alat bantu diagnostik tambahan terutama pada kasus yang tidak komplet atau meragukan.

\section{Daftar pustaka}

1. Nakamura Y. Kawasaki disease: epidemiology and the lessons from it. Int J Rheum Dis 2018;21:16-9.

2. Advani N. Penyakit Kawasaki: Faktor risiko terjadinya aneurisme koroner, perjalanan klinisnya, serta jumlah dan kualitas sel progenitor endotel [disertasi]. Jakarta: Universitas Indonesia; 2014.

3. Newburger JW, Takahashi M, Gerber MA, Gewitz MH, Tani LY, Burns JC, dkk. Diagnosis, treatment, and longterm management of Kawasaki disease: A statement for health professionals from the committee on rheumatic fever, endocarditis and Kawasaki disease, Council on Cardiovascular Disease in the Young, American Heart Association. Circulation 2004;110:2747-71.

4. Umezawa T, Saji T, Matsuo N, Odagiri K. Chest x-ray findings in the acute phase of Kawasaki disease. Pediatr Radiol 1989;20:48-51.

5. Moriya S, Aoki J, Tashiro M, Taketomi-Takahashi A, Tsushima Y. Peribronchovascular haze: a frequently observed finding on chest X-rays in the acute phase of Kawasaki disease. Jpn J Radiol 2014;32:38-43

6. Uramoto K, Ikawa A, Ri K, Watanabe C, Suzuki A, Kiguchi $\mathrm{H}$, dkk. Study of chest x-ray findings in Kawasaki disease. Shoni Naika 1978:10:320.

7. Amano S, Hazama F, Kubagawa H, Tasaka K, Haebara H, Hamashima Y. General pathology of Kawasaki disease on the morphological alterations corresponding to the clinical manifestation. Acta Pathol Jpn 1980;30:681-94. 